can call its own as because of need. But it would be far preferable if the two quite complicated organizations which have grown up in the past decade were not simply married but merged, and if member countries were compelled to agree that membership would not allow them to contract out of parts of the programme with which they did not happen to agree. It must be confessed, of course, that such a happy turn of events would be possible only if there were a thorough and independent study of the basis on which a programme of work might be hammered out, for this is a field in which civil servants, however wise, are unlikely to carry conviction and persuade the sceptics. Until such a study can be completed and approved politically, the European governments should give up the pretence that they can conjure a space programme out of thin air simply by setting a date for the conference postponed from October.

\section{Modest Shufille}

Mr EdWaRd Heath has now made the rearrangement of government posts for the new session of parliament that would no doubt have been made a week ago if the government had not been locked in its fruitless discussions with the trades unions and the Confederation of British Industry. Modest though the changes are, their consequences for the management of British science and technology could be considerable, chiefly because of the replacement of Mr John Davies by Mr Peter Walker as Secretary of State at the Department of Trade and Industry. Even before this organization was created by the merging together of the Ministry of Technology and the old Board of Trade, it had become clear that its scale and complexity were a formidable problem of management and of policy making outdone only by the Department of Health, Education and Welfare in the United States, popularly (and rightly) known as the anthill. Mr Davies has not been a great success, even if it may not be entirely his own fault that he was forced to swallow his brave words about the government's unwillingness to help lame ducks, but his experience at the Department of Trade and Industry should help him considerably in his new task of coordinating British government policy towards Europe, for it is clear that the most urgent tasks are grounded in industry and technology. Whether Mr Walker makes a better showing at the Department of Trade and Industry will no doubt depend on his success in preventing too much of his undoubted enthusiasm and energy from being sapped by his passion for trendiness.

There are several urgent issues crying out for his attention. Although the British government is still boasting of its success at the Paris summit meeting in winning approval for a European Regional Development Fund, it remains in something of a muddle about objectives. Is regional policy a device for ensuring that the present distribution of industry in Britain should be preserved indefinitely, or is it a means of helping regions dependent on declining industries over their short-term problems (in which case the link with arrangements for social security should be stronger than it is)? This is an issue into which $\mathrm{Mr}$ Walker could quickly sink his teeth. Another is the question of how best to strike a balance between the department's activities in research and development. In the current financial year, the department is spending £167.9 million on research and development for civil aircraft projects but only $£ 68.7$ million on industrial research and development in all other civil fields. Is this a sensible allocation of priorities? Has not the time come for a much harder-headed agreement on the pooling of civil aviation on a European basis? Is there not also scope for similar arrangements where such programmes as the development of fast reactors and the management of standards and metrology laboratories are concerned? And, although the benefits of a more sensible pooling of European effort might not be so much to economize in running costs as to improve efficiency, is it not time that the Department of Trade and Industry began to think of playing a much more decisive part in general research and development in industry as a whole? In the current year, only £14.1 million is set aside for work like this (but the department has found it necessary to lend as much again to International Computers Limited for a similar purpose). It could easily be that Mr Walker's most valuable contribution to the years ahead would be to devise a sensible way of channelling public funds to industry. And then there are specific issues to be decided such as the working out of a clear policy on European space research and development.

The other change in Mr Heath's shuffle which will influence the administration of science and technology is the replacement of $\mathrm{Mr}$ William van Straubenzee by Mr Norman St John Stevas at the Department of Education and Science. But here it must be acknowledged that the change is unimportant. In Mr Heath's government, the Department of Education and Science has been unnecessarily monolithic, with Mrs Margaret Thatcher involved in every aspect of the work and with the Parliamentary Under-Secretary of State left with unpalatable tasks such as negotiations with the National Union of Students. But the technical problems of managing higher education and those parts of scientific research left with the department are fearsome and likely to become even more so in the months ahead, as the new Advisory Board on the Research Councils will quickly demonstrate. It would have been sensible of the Prime Minister to have gone back to the pattern of the 1960s and to have appointed a Minister of State with special responsibility for science and higher education.

\section{Power to Which People?}

IN the past few months, $\mathrm{Mr}$ Tony Benn (alias $\mathrm{Mr}$ Anthony Wedgwood Benn) has made most of the running in Britain in public discussion of the nature of democracy and has incurred more derision than such an important subject deserves, possibly because of the manner in which he has argued his case and because of the oldfashioned concepts which run through his arguments. The essence of his case was well put in a speech to the Guild of Newspaper Editors at Bournemouth in April this year, the full text of which has only now been made public. He starts from the premise that the problem of modern democracy is not that of involving people in the processes of government but that of somehow gaining 